\title{
Influence of Growing Media on Vegetative, Floral and Bulb Parameters of Crown Lily (Fritillaria Imperialis L.)
}

\section{Reyaz Ahmad Bhat ${ }^{1 *}$, ZA Bhat ${ }^{1}$, Sadaf Rafiq ${ }^{1}$, IT Nazki ${ }^{1}$, FU Khan ${ }^{1}$, Neelofar ${ }^{1}$, ZA Rather ${ }^{1}$, Nasir Masoodi ${ }^{1}$, Qazi Altaf ${ }^{1}$ and Rauoof Ahmad Rather $^{2}$}

${ }^{1}$ Division of Floriculture and Landscape Architecture, Faculty of Horticulture, SKUAST-K, Shalimar Campus, Jammu and Kashmir, India

${ }^{2}$ Division of Environmental Sciences, SKUAST-K, Shalimar Campus, Jammu and

Kashmir, India

*Corresponding Author: Reyaz Ahmad Bhat, Division of Floriculture and Landscape Architecture, SKUAST-K, Shalimar Campus, Srinagar 190025, Jammu and Kashmir, India
Received: March 02, 2021

Published: March 16, 2021

(C) All rights are reserved by Rauof Ahmad., et al.

\begin{abstract}
An experiment entitled "Standardization of Growing Media for Pot Culture of Crown Lily (Fritillaria imperialis L.)" was carried out at the Floricultural experimental field SKUAST-K during the year 2017-18. The investigation involved 11 treatment combinations $\left(\mathrm{T}_{1}=\right.$ Soil/control, $\mathrm{T}_{2}=$ Soil + Sand 1:1, $\mathrm{T}_{3}=$ Soil + Sand 2:1, $\mathrm{T}_{4}=$ Soil +Sand +FYM 1:1:1, $\mathrm{T}_{5}=$ Soil + Sand + FYM 1:1:2, $\mathrm{T}_{6}=$ Soil + Sand + Vermicompost 1:1:1, $\mathrm{T}_{7}=$ Soil + Sand + Vermicompost 1:1:2, $\mathrm{T}_{8}=$ Soil +Sand + Sheep manure 1:1:1, $\mathrm{T}_{9}=$ Soil + Sand + Sheep manure 1:1:2, $\mathrm{T}_{10}=$ Soil + Sand + Forest litter 1:1:1 and $\mathrm{T}_{11}=$ Soil + Sand + Forest litter 1:1:2) laid out in triplicate Completely Randomized Design (CRD). The results of the study revealed that the treatment $\mathrm{T}_{11}$ (Soil +Sand + Forest litter 1:1:2) significantly improved vegetative, floral and yield attributes of crown lily. Maximum plant height $(73.47 \mathrm{~cm})$, number of leaves plant ${ }^{-1}(63.33)$, floret length $(5.87 \mathrm{~cm})$, weight of main bulb (149.25 g), number of bulblets per bulb (2.00) was recorded in treatment $\mathrm{T}_{11}$ (Soil +Sand + Forest litter 1:1:2) while as the minimum plant height $(61.00 \mathrm{~cm})$, number of leaves plant ${ }^{-1}(50)$, floret length $(4.33 \mathrm{~cm})$, weight of main bulb $(141$. g), number of bulblets bulb ${ }^{-1}(1.00)$ was recorded in treatment $\mathrm{T}_{1}$ (control/Soil).
\end{abstract}

Keywords: Crown Lily; Bulb; Media; Growth; Yield

\section{Introduction}

Fritillaria imperialis L. is by far the most well-known species and the most impressive perennial bulbous flowering plant. It is native to locations such as Turkey, Iraq, Iran, Afghanistan, Pakistan and Himalayan foot hills including Kashmir valley [10]. Crown imperial reaches up to $100-110 \mathrm{~cm}$ tall with a thick, stout, upright, ramrod-straight flowering stem bearing lance-shaped, glossy leaves with wavy margins around the lower half of the stem. Each stem is topped by spectacular clusters of orange, yellow or red pendant bell shaped flowers with a crown of small leaves. The common name, tears of Mary refers to the drops of nectar at the base of each petal, Christian tradition tells that of all the flowers, only the proud crown imperial refused to bow its head at the crucifixion it has bowed and wept ever since. The flowers emit a distinctly foxy smell that's reputed to repel mice and moles.

The genus Fritillaria belongs to the subclass Monocotyledonae and family Liliaceae. The genus includes about 100 species native to temperate climatic zones of the Northern Hemisphere [6]. Crown lily has big and attractive bell-shaped florets, so it is being used as a cut flower, pot plant and in landscape design and has revealed a great commercial potential [5]. Crown lily is also having high medicinal properties. The bulbs are diuretic and emollient. Bulbs are regarded as a natural resource in the medical sector because 
they contain steroids, which are effective substances [3]. Its bulb is an important source of anti-tussive, expectorant and anti-hypertensive drugs and has high starch content so can be considered as new starch source for the food and medicine industry [11] and is an important source of steroidal alkaloids which have cholinesterase inhibiting role [2]. Use of suitable growing media or substrates is essential for the production of quality horticultural crops. Increasing utilization of available land for physical and infrastructural development rapidly declines the supply of quality top Soil and thus promoting the utilization of Soilless materials in the production of horticultural crops [1].

There is absolutely no data available with regard to suitable growing media that could augment better productivity of the crop in pot culture. The growing media which is an important determinant of productivity in pot culture still remains to be standardized. Keeping in view the above facts, the present investigation was proposed to carry out with the following objective: To find out suitable growing media for growth and flowering on pot culture of Crown lily (Fritillaria imperialis L.).

\section{Material and Methods}

A field experiment was carried out at the floriculture experimental field, Sher-e-Kashmir University of Agricultural Sciences and Technology of Kashmir, Shalimar Srinagar, during the year 2017-18. In the investigation, different growing media were prepared using Sand, Soil, Farm Yard Manure, Forest litter, Sheep manure and Vermicompost in different proportions $\left(\mathrm{T}_{1}=\right.$ Soil/control, $\mathrm{T}_{2}=$ Soil + Sand 1:1, $\mathrm{T}_{3}=$ Soil + Sand 2:1, $\mathrm{T}_{4}=$ Soil +Sand +FYM 1:1:1, $\mathrm{T}_{5}=$ Soil + Sand + FYM 1:1:2, $\mathrm{T}_{6}=$ Soil +Sand + Vermicompost 1:1:1, $\mathrm{T}_{7}=$ Soil + Sand + Vermicompost 1:1:2, $\mathrm{T}_{8}=$ Soil +Sand + Sheep manure 1:1:1, $\mathrm{T}_{9}=$ Soil + Sand + Sheep manure 1:1:2, $\mathrm{T}_{10}=$ Soil + Sand + Forest litter 1:1:1 and $\mathrm{T}_{11}=$ Soil +Sand + Forest litter 1:1:2). Experiment was laid out in a randomized block design with three replications. Bulbs were planted in pots, uniform sized Fritillaria bulbs were selected for the experimentation. Before planting, bulbs were treated in a solution comprising of Bavistin (0.1\%) and Dithane M-45 (0.2\%) for 30 minutes. The excess water is drained out and bulbs were planted at a depth of $10-12 \mathrm{~cm}$ with 1 bulb per pot. The optimum moisture level was maintained in the medium by spraying water depending on the requirement. Uniform cultural practices were followed during experiment. Observations were recorded carefully for the flowering and corm parameters and subjected to statistical analysis.

\section{Results and Discussion}

All the vegetative, flowering and bulb parameters were significantly influenced by different treatments, with regard to vegetative growth like plant height, number of leaves /plant, leaf area, stalk thickness and bulb sprouting of the crop. The appraisal of data recorded revealed that among all the treatments, treatment $\mathrm{T}_{11}$ (1 Soil +1 Sand + 2 Forest litter) significantly influenced the vegetative parameters as depicted by their highest numerical values (Table 1). The results of influences the growth of fritillary with the Forest litter might be due to the fact that the crop is phylogenitically adapted to the wild climate of coniferous Forests. Forest litter acts as an excellent growing media in terms of holding moisture, improving the porosity of Soil and harbouring the symbiotic microorganisms and Soil arthropods. The complexity of the bulb and Forest Soil/litter relationship is yet to be unravelled. The probable reasons of hassle-free growing of Fritillaria imperialis L. in Forest litter might be also due to the symbiotic relationship of crop bulb with the surrounding media, as its well-known that the bulbs of Fritillaria imperialis $\mathrm{L}$. are exuding some chemicals those might be beneficial in improving the Soil microbe/arthropod quantum hence the results. Furthermore, Forest ecosystem arthropod communities play a vital role in decomposition and production of humus $[4,5]$. Humus is considered an important media for bulbous growth this might have influenced the sturdy vegetative growth of Fritillaria imperialis L.

While comparing the results of different growing media on floral and seed characteristics of Fritillaria imperialis L., astonishingly

\begin{tabular}{|l|c|c|c|c|}
\hline Treatment & $\begin{array}{c}\text { Days to Bulb } \\
\text { Sprouting } \\
\text { (mean) }\end{array}$ & $\begin{array}{c}\text { Plant Height at } \\
\text { Flowering (cm) }\end{array}$ & $\begin{array}{c}\text { No. of } \\
\text { leaves } \\
\text { plant }\end{array}$ & $\begin{array}{c}\text { Leaf } \\
\text { area } \\
\text { (cm }{ }^{2}\end{array}$ \\
\hline $\mathrm{T}_{1}$ & 156.33 & 61.00 & 50.00 & 2995.00 \\
\hline $\mathrm{T}_{2}$ & 152.50 & 61.67 & 52.00 & 3004.33 \\
\hline $\mathrm{T}_{3}$ & 151.00 & 62.67 & 53.00 & 3006.20 \\
\hline $\mathrm{T}_{4}$ & 148.33 & 64.88 & 53.33 & 3009.43 \\
\hline $\mathrm{T}_{5}$ & 147.00 & 66.45 & 54.00 & 3027.33 \\
\hline $\mathrm{T}_{6}$ & 149.00 & 68.60 & 60.00 & 3052.67 \\
\hline $\mathrm{T}_{7}$ & 146.50 & 69.18 & 63.00 & 3068.33 \\
\hline $\mathrm{T}_{8}$ & 148.00 & 67.90 & 60.33 & 3051.00 \\
\hline $\mathrm{T}_{9}$ & 147.00 & 68.50 & 62.00 & 3053.33 \\
\hline $\mathrm{T}_{10}$ & 150.67 & 68.78 & 61.33 & 3052.60 \\
\hline $\mathrm{T}_{11}$ & 146.00 & 73.47 & 63.33 & 3070.00 \\
\hline C.D (p $\leq$ & 3.96 & 3.15 & 2.30 & 4.26 \\
\hline 0.05$)$ & & & & \\
\hline
\end{tabular}

Table 1: Effect of growing media on vegetative of Fritillaria imperialis $\mathrm{L}$. 
to our results the impact of treatment $\mathrm{T}_{11}(1$ Soil +1 Sand +2 Forest litter) was significant in influencing the floral and seed attributes of Fritillaria imperialis L. viz., days to floral bud emergence, days to flower opening, number of florets/plant, inflorescence diameter, floret diameter/length, days to senescence, presentability and seed set (Table 2). The sturdy growth and vigour of the crop were recorded among the treatment having more Forest litter $\left(\mathrm{T}_{11}\right)$. The tendency of more vigoursity increases with increased partiality of shade. The results reflect the fact that the crop Fritillaria imperialis L. is more adapted to grow freely under its corresponding natu- ral habitat and climate conditions. The results indicated the crop specificity towards the edaphic conditions. The improved results of floral and seed parameters are reflected to the fact that the organisms (especially geophytes) are more responsive when subjected to the natural culturing media (Forest Soil), this perhaps might be due to the complex physiological and chemical interaction between the underground growth and the composition of the active ingredients present within the potting/culturing media. The complexity of bulb physiology and mechanism of its corresponding interaction with the growing media need to be discussed and elaborated further.

\begin{tabular}{|l|c|c|c|c|c|c|c|c|c|}
\hline $\begin{array}{c}\text { Treatment } \\
\text { codes }\end{array}$ & $\begin{array}{c}\text { Stalk } \\
\text { thickness } \\
\text { (cm) }\end{array}$ & $\begin{array}{c}\text { Days took to } \\
\text { floral bud } \\
\text { appearance }\end{array}$ & $\begin{array}{c}\text { Days to } \\
\text { flower } \\
\text { opening }\end{array}$ & $\begin{array}{c}\text { No. of } \\
\text { florets }\end{array}$ & $\begin{array}{c}\text { Inflorescence } \\
\text { diameter (cm) }\end{array}$ & $\begin{array}{c}\text { Floret } \\
\text { diameter } \\
\text { (cm) }\end{array}$ & $\begin{array}{c}\text { Floret } \\
\text { length (cm) } \\
\text { mean }\end{array}$ & $\begin{array}{c}\text { Present- } \\
\text { ability score } \\
\text { (out of 100) }\end{array}$ & $\begin{array}{c}\text { Days to } \\
\text { senescence } \\
\text { (flower) }\end{array}$ \\
\hline $\mathrm{T}_{1}$ & 1.34 & 172 & 186.02 & 3.33 & 7.3 & 4.98 & 4.33 & 73.2 & 16.67 \\
\hline $\mathrm{T}_{2}$ & 1.53 & 171.33 & 184.17 & 4 & 7.84 & 4.57 & 5.13 & 73.6 & 17.33 \\
\hline $\mathrm{T}_{3}$ & 1.61 & 170.33 & 183.71 & 4.66 & 8.57 & 4.38 & 5.16 & 74 & 18.5 \\
\hline $\mathrm{T}_{4}$ & 1.67 & 166.67 & 181.23 & 5 & 9.13 & 4.35 & 5.17 & 76.43 & 18.33 \\
\hline $\mathrm{T}_{5}$ & 1.74 & 166.67 & 179.78 & 5.33 & 9.3 & 4.06 & 5.76 & 78.43 & 19.17 \\
\hline $\mathrm{T}_{6}$ & 1.74 & 167 & 178.51 & 5.33 & 9.21 & 4.11 & 5.59 & 77.5 & 18.83 \\
\hline $\mathrm{T}_{7}$ & 1.88 & 165.33 & 174.44 & 6 & 10.33 & 3.86 & 5.79 & 83.37 & 21.83 \\
\hline $\mathrm{T}_{8}$ & 1.51 & 167 & 180.02 & 5.67 & 9.8 & 4.17 & 5.64 & 77.77 & 18.5 \\
\hline $\mathrm{T}_{9}$ & 1.42 & 165.67 & 177 & 6 & 10.13 & 3.87 & 5.74 & 79.4 & 19.5 \\
\hline $\mathrm{T}_{10}$ & 1.55 & 166.33 & 178.67 & 5.33 & 9.33 & 4.07 & 5.36 & 78.43 & 19.33 \\
\hline $\mathrm{T}_{11}$ & 1.92 & 164 & 174.16 & 6.67 & 10.57 & 3.33 & 5.87 & 84.2 & 22.33 \\
\hline C.D (p & 0.249 & 0.07 & 0.34 & 0.785 & 0.153 & 0.7 & 0.716 & 0.47 & 0.756 \\
\hline 0.05$)$ & & & & & & & & \\
\hline
\end{tabular}

Table 2: Effect of growing media on floral characters of Fritillaria imperialis.

Taking into consideration the economic importance of Fritillaria imperialis $\mathrm{L}$. bulbs as indicated by the fact that a single bulb price ranges from 150-200 INR in Indian and as well as in Kashmir markets. The investigation was further extended to evaluate the response of Fritillaria imperialis L. bulbs towards different proportions and the type of growing/potting media. The investigation is first of its kind to be evaluated under Kashmir conditions. To our observation, the rate of multiplication, size and weight of bulbs were significantly impacted when the crop was subject to growing media containing 1 Soil +1 Sand +2 Forest litter $\left(T_{11}\right)$ (Table 3 ). It's noteworthy that the results may seem statistically significant but while comparing to the same treatment the improvement in the aforementioned observations was seen beyond the normal under shade conditions. Thus to our opinion, the growth and bulb pro- duction of Fritillaria imperialis L. could be further improved if the crop is subjected to an artificial or natural shade. Furthermore, the physical properties of Forest litter (like movement of water in both vertical and horizontal direction, water retention capacity, nutrient status, porosity and the presence of some beneficial microorganisms and arthropods) and the intrinsic relationship between the bulb and media are having a tremendous influence on any geophytes especially the Fritillaria imperialis L. crop. Soil microbial activity and biomass varies with crop species and is dependent on various factors like Soil moisture, temperature, Soil texture, organic matter content etc. [9]. Furthermore, the presence of dissolved organic matter (DOM) Forest Soils plays an important role in cycling and availability of nutrients to plants [8], consequently all these factors might have contributed to improved yield attributes. 
Furthermore, Fritillaria growing in media containing Forest litter showed the increased leaf area as well as leaf thickness, therefore, producing more photo-assimilates and thus total photosynthetic capacity might have also provided greater photosynthates to the bulb and helpful in increasing the number as well as the fresh weight of the bulbs.

\begin{tabular}{|l|c|c|c|c|}
\hline $\begin{array}{c}\text { Treatment } \\
\text { codes }\end{array}$ & $\begin{array}{c}\text { Number of } \\
\text { seeds set per } \\
\text { plant (Mean) }\end{array}$ & $\begin{array}{c}\text { Bulb } \\
\text { weight } \\
\text { (g) }\end{array}$ & $\begin{array}{c}\text { Bulb size } \\
\text { (cm) }\end{array}$ & $\begin{array}{c}\text { Number } \\
\text { of bulbs }\end{array}$ \\
\hline $\mathrm{T}_{1}$ & 626.33 & 141 & 6.37 & 1 \\
\hline $\mathrm{T}_{2}$ & 634.67 & 140.33 & 6.66 & 1 \\
\hline $\mathrm{T}_{3}$ & 639.67 & 143.13 & 6.68 & 1.33 \\
\hline $\mathrm{T}_{4}$ & 641.03 & 145.03 & 6.53 & 1 \\
\hline $\mathrm{T}_{5}$ & 651.67 & 146.67 & 6.59 & 1.33 \\
\hline $\mathrm{T}_{6}$ & 659.33 & 145.07 & 6.7 & 1.33 \\
\hline $\mathrm{T}_{7}$ & 701.33 & 148.63 & 6.97 & 1.67 \\
\hline $\mathrm{T}_{8}$ & 691 & 144.24 & 6.43 & 1.33 \\
\hline $\mathrm{T}_{9}$ & 685.19 & 147.29 & 6.8 & 1.33 \\
\hline $\mathrm{T}_{10}$ & 687.48 & 146.79 & 6.79 & 1 \\
\hline $\mathrm{T}_{11}$ & 701.65 & 149.25 & 7.22 & 2 \\
\hline C.D $(\mathrm{p} \leq 0.05)$ & 7.97 & 3.87 & 0.401 & 0.55 \\
\hline
\end{tabular}

Table 3: Effect of growing media on yield characters of Fritillaria imperialis L.

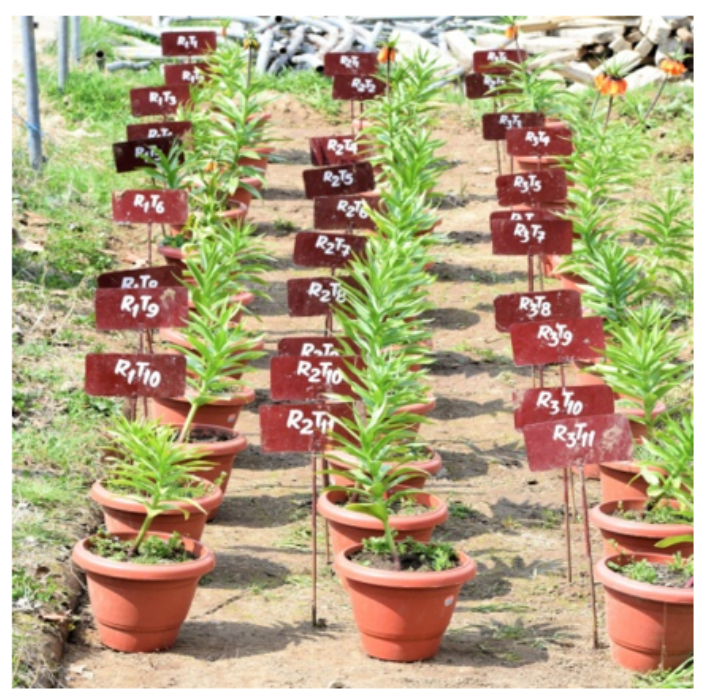

Figure 1: General view of trial.

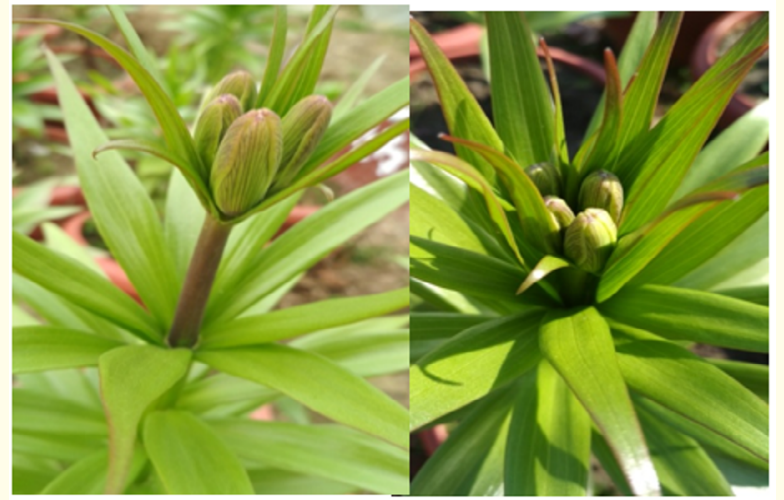

Figure 2: Flower bud emergence.
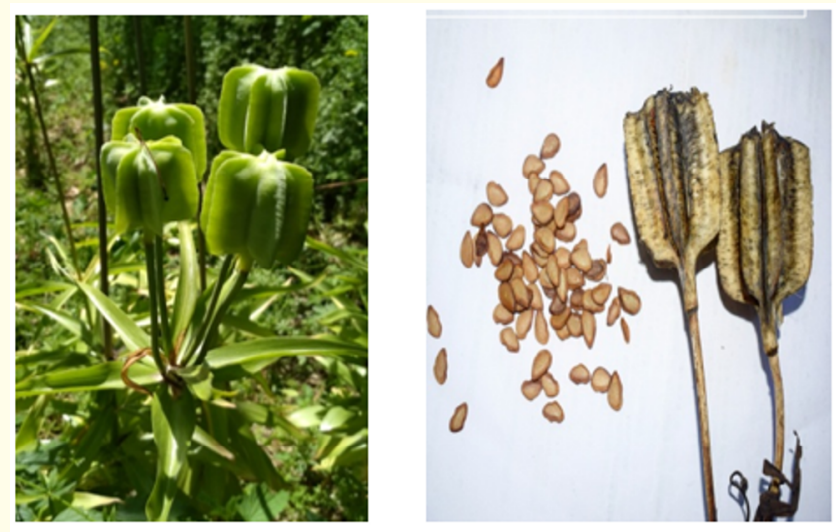

Figure 3: Seed of Fritillaria Imperialis.

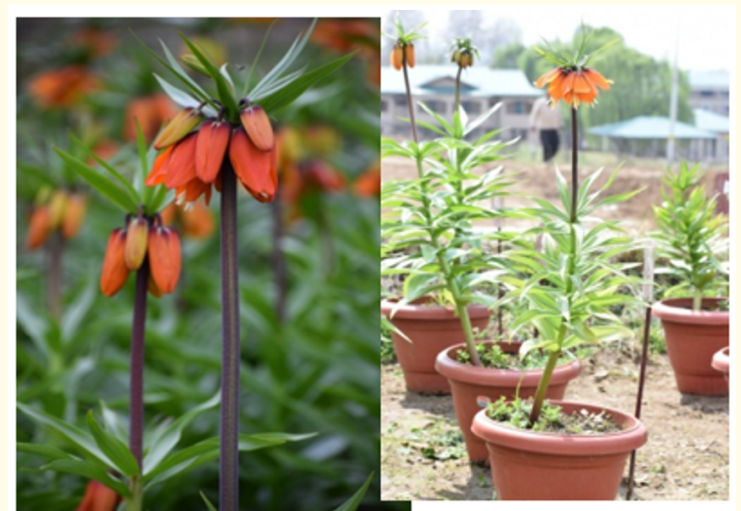

Figure 4: Flowering stage of crop. 

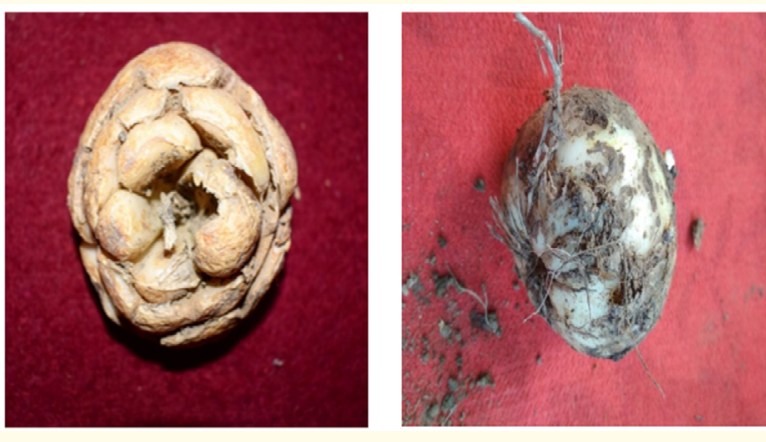

Figure 5: Bulb of Fritillaria Imperialis.

\section{Conclusion}

Based upon the study i.e., "To find out suitable growing media for growth and flowering on pot culture of Crown lily (Fritillaria imperialis L.)" it is concluded that the treatment $\mathrm{T}_{11}$ (Soil+ Sand + Forest litter; $1: 1: 2 ; \mathrm{v} / \mathrm{v}$ ) resulted in sturdy vegetative growth, quality floral attributes and higher bulb yield in Fritillaria imperialis $\mathrm{L}$.

\section{Bibliography}

1. Abad M., et al. "Physico-chemical and chemical properties of some coconut dust for use as a peat substitute for containerized ornamental plants". Bioresource Technology 82 (2002): 241-245.

2. Atta-ur-rahman MNA., et al. "New steroidal alkaloids from Fritillaria imperialis and their cholinesterase inhibiting activities". Chemical Pharmaceutical Bulletin 50 (2002): 1013-1016.

3. Bingol F., et al. "Biological activities of some Fritillaria species growing in Turkey”. 13 (1996): 45.

4. Bird S., et al. "The limit value of plant litter decomposing in two contrasting Soils- an influence of litter elemental composition". Acta Oecologica 24 (2000): 294-302.

5. De Hertog A and Le Nard M. "The physiology and biochemical aspects of flower bulbs. In: Physiology of flower bulbs (eds. De Hertog, A.A. and Le Nard, M.)”. Elsevier. Amsterdam (1993): 55-69.

6. Ekim T., et al. "Exported flower bulbs from Turkey and measurements taken”. Acta Horticulture 325 (1992): 861-866.

7. Hebert BE and Bertsch PM. "Characterization of dissolved and colloidal organic matter in Soil solutions: A review". In: Kelly
JM, McFee WW (Eds) Carbon forms and function in Forest Soils. Soil science society of America (1995): 63-88.

8. Kramer S and Green DM. "Acid and alkaline phosphatase dynamics and their relation to Soil microclimate in a semiarid woodland". Soil Biology and Biochemistry 34 (2000): 179-188.

9. Ponge J F., et al. "Caracterixation des humus et des litiers par la faune du sol interet sylvicol". Revue Forestiere Farancaise 38 (1986): 509-516.

10. Tubives (2007) http://www.tubitak.gov.tr/tubives.

11. Wang S H., et al. "New starches from Fritillaria species medicinal plants". Carbohydrate Polymer 61 (2005): 111-114.

\section{Assets from publication with us}

- Prompt Acknowledgement after receiving the article

- Thorough Double blinded peer review

- Rapid Publication

- Issue of Publication Certificate

- High visibility of your Published work

Website: www.actascientific.com/

Submit Article: www.actascientific.com/submission.php Email us: editor@actascientific.com

Contact us: +919182824667 